\title{
Phaeocystis colony distribution in the North Atlantic Ocean since 1948, and interpretation of long-term changes in the Phaeocystis hotspot in the North Sea
}

\author{
W. W. C. Gieskes • S. C. Leterme • \\ H. Peletier • M. Edwards • P. C. Reid
}

Received: 13 October 2005 / Accepted: 12 June 2006 / Published online: 10 March 2007

(C) Springer Science+Business Media B.V. 2007

\begin{abstract}
Monitoring of Phaeocystis since 1948 during the Continuous Plankton Recorder survey indicates that over the last 5.5 decades the distribution of its colonies in the North Atlantic Ocean was not restricted to neritic waters: occurrence was also recorded in the open Atlantic regions sampled, most frequently in the spring. Apparently, environmental conditions in open ocean waters, also those far offshore, are suitable for complete lifecycle development of colonies (the only stage recorded in the survey).

In the North Sea the frequency of occurrence was also highest in spring. Its southeastern part was the Phaeocystis abundance hotspot of the whole area covered by the survey. Frequency was especially high before the 1960s and after the
\end{abstract}

W. W. C. Gieskes

Department of Ocean Ecosystems,

University of Groningen, Haren, The Netherlands

e-mail: gieskess@xs4all.nl

S. C. Leterme

M.B.E.R.C., School University of Plymouth,

Plymouth, PL4 8AA, UK

H. Peletier

R.I.K.Z.-Rijkswaterstaat, Haren,

The Netherlands

S. C. Leterme $(\varangle) \cdot$ M. Edwards · P. C. Reid

S.A.H.F.O.S., Citadel Hill,

Plymouth, PL1 2PB, UK

e-mail: sophie.leterme@plymouth.ac.uk 1980s, i.e., in the periods when anthropogenic nutrient enrichment was relatively low. Changes in eutrophication have obviously not been a major cause of long-term Phaeocystis variation in the southeastern North Sea, where total phytoplankton biomass was related significantly to river discharge. Evidence is presented for the suggestion that Phaeocystis abundance in the southern North Sea is to a large extent determined by the amount of Atlantic Ocean water flushed in through the Dover Strait.

Since Phaeocystis plays a key role in element fluxes relevant to climate the results presented here have implications for biogeochemical models of cycling of carbon and sulphur. Sea-to-air exchange of $\mathrm{CO}_{2}$ and dimethyl sulphide (DMS) has been calculated on the basis of measurements during single-year cruises. The considerable annual variation in phytoplankton and in its Phaeocystis component reported here does not warrant extrapolation of such figures.

Keywords Annual variation - North Sea hotspot North Atlantic-wide $\cdot$ Phaeocystis

\section{Introduction}

In the North Atlantic and the North Sea seasonal variations in marine phytoplankton composition are well known, but annual variations in abundance 
have hardly been described, with only a few exceptions. Monitoring has been maintained for several decades close to British (Russell et al. 1971), Dutch (Cadée and Hegeman 1991), German (Hickel et al. 1996) research institutes, off Belgium between 1988 and 2000 (Breton et al. 2006). Observed changes in plankton have been related to shifts in ocean current patterns (Russell 1935, 1973; Lindley et al. 1990; Taylor et al. 1998; Reid et al. 2003) that are assumed to be governed by large-scale meteorological phenomena (Beaugrand et al. 2002; Edwards et al. 2002; Reid and Edwards 2001; Drinkwater et al. 2003; Leterme et al. 2005; Breton et al. 2006), to climate (Radach 1984; Seuront and Souissi 2001; Reid et al. 1998), or to increased coastal eutrophication (Richardson 1989, 1997; Greve et al. 1996), but the response of plankton to anthropogenic interference (Cadée and Hegeman 2002; Beaugrand 2004) has not always been demonstrated in a convincing way.

The Continuous Plankton Recorder survey is the longest-running monitoring programme in the North Atlantic and the North Sea, with a remarkably wide coverage (Fig. 1a), based on one standard sampling method (Glover 1967; Colebrook 1975; Warner and Hays 1995). Since the time series spans several decades, it has been tempting to interpret striking changes in abundance of the plankton caught on the nets ('silks') of Hardy's recorders as the consequence of long-term environmental change because variations often took place simultaneously over very large areas (Colebrook and Robinson 1964; Edwards et al. 2002). Actually, it has often been taken for granted that hydroclimatic forcing in relation to global warming must have controlled the long- and short-term plankton variability. The northward shift in subtropical and temperate zooplankton groups and the gradual disappearance of coldadapted copepod species in the eastern North Atlantic (Beaugrand et al. 2002) has indeed been quite conspicuous. However, trends in ocean water temperature, in the Atlantic multidecadal oscillation, or in the state of the North Atlantic oscillation and related hydrographical features (e.g., vertical stratification: Martin and Hall 1975; Fromentin and Planque 1996, Reid et al. 2001) could often only be related to the abundance of plankton components and transitions in taxonomic composition after sophisticated statistical treatment (Beaugrand et al. 2000, 2003; Beaugrand 2004) or on assumptions involving differential lags in the response of ecosystem components (Drinkwater et al. 2003; Kane 2005).

The Continuous Plankton Recorder survey has provided a tremendous data set on the occurrence of Phaeocystis sp. Phaeocystis was already known to vary as much as any other group of plankton in the North Atlantic (Owens et al. 1989) and the North Sea, in a way apparently independent of the phytoplankton in general or of other microalgal species groups such as dinoflagellates and diatoms (Gieskes and Kraay 1977a), for reasons not known at the time. We present here an overview of the occurrence of Phaeocystis throughout the North Atlantic. In our discussion we will focus on its presence in the North Sea, where it is most abundant. We offer an attempt to link occurrence to the pattern of long-term change in hydrographic events in the eastern North Atlantic. We end the presentation of our analysis by highlighting the biogeochemical implications of the longterm changes in the abundance of this species, which is known to affect profoundly the cycling and sea-to-air exchange of climate-relevant elements, especially carbon and sulphur, components in the greenhouse gases $\mathrm{CO}_{2}$ and dimethyl sulphide (DMS; see review by Schoemann et al. 2005).

\section{Materials and methods}

\section{The Continuous Plankton Recorder}

The Continuous Plankton Recorder (CPR) survey consists of a dense network of transects across the North Atlantic and the North Sea. Plankton recorders are towed on a monthly basis at a depth of 8-10 m from ships-of-oppportunity that travel at $10-18$ knots. The sampling mechanism inside the recorders consists of a narrow band of filtering silk (mesh $270 \mu \mathrm{m}$ ) that is driven by an impeller at the rear of the recorder at a speed adjusted according to the speed of the ship. The silk catches particles entering the $12 \mathrm{~mm}^{2}$ aperture while it passes (at a rate of $10 \mathrm{~cm}$ per 10 nautical miles, $18.5 \mathrm{~km}$ ) through the end of a wide tunnel behind the narrow opening in front. About $3 \mathrm{~m}^{3}$ 
of seawater is filtered every $18.5 \mathrm{~km}$. Clogging of silks is an exception, but it happens.

Phaeocystis colonies are recorded visually as present or absent on lengths of $10 \mathrm{~cm}$ of silk (a sample). From this information a time series from all the CPR samples for a given region can be used to create maps of the frequency of occurrence (the percentage of samples with Phaeocystis presence). $0 \%$ means that for a given month not a single sample contained Phaeocystis, $100 \%$ that it was present (no matter how much) in every single sample taken in that month. Each section covered by the CPR constitutes a variable number of samples. Total coverage of a section is determined as an average of all percentages.

Details of the sampling procedure have been described by Warner and Hays (1995). Total phytoplankton biomas' is assessed in four categories by comparing the colouration of the silks (mostly caused by algal pigments) with a colour chart. The colour values [Phytoplankton Colour index (PCI)] are related to chlorophyll concentration on the silks and in the field (Gieskes and Kraay 1977a; Batten et al. 2003).

Standard regions of the CPR survey are shown in Fig. 1a; each consists of smaller rectangles; rectangle 'Ow', located in the southeastern part of the Southern Bight of the North Sea just off The Netherlands where major rivers of the continent (Rhine, Scheldt) discharge, has received particular attention in the present study.

\section{Rijkswaterstaat-RIKZ survey}

The chlorophyll concentrations of the monitoring programme run by Rijkswaterstaat-RIKZ off The
Fig. 1 (a) Standard areas of the continuous plankton recorder survey. (b)Distribution of Phaeocystis colonies over the North Atlantic and the North Sea over the years 1948-2003. Annual variations: see Fig. 2
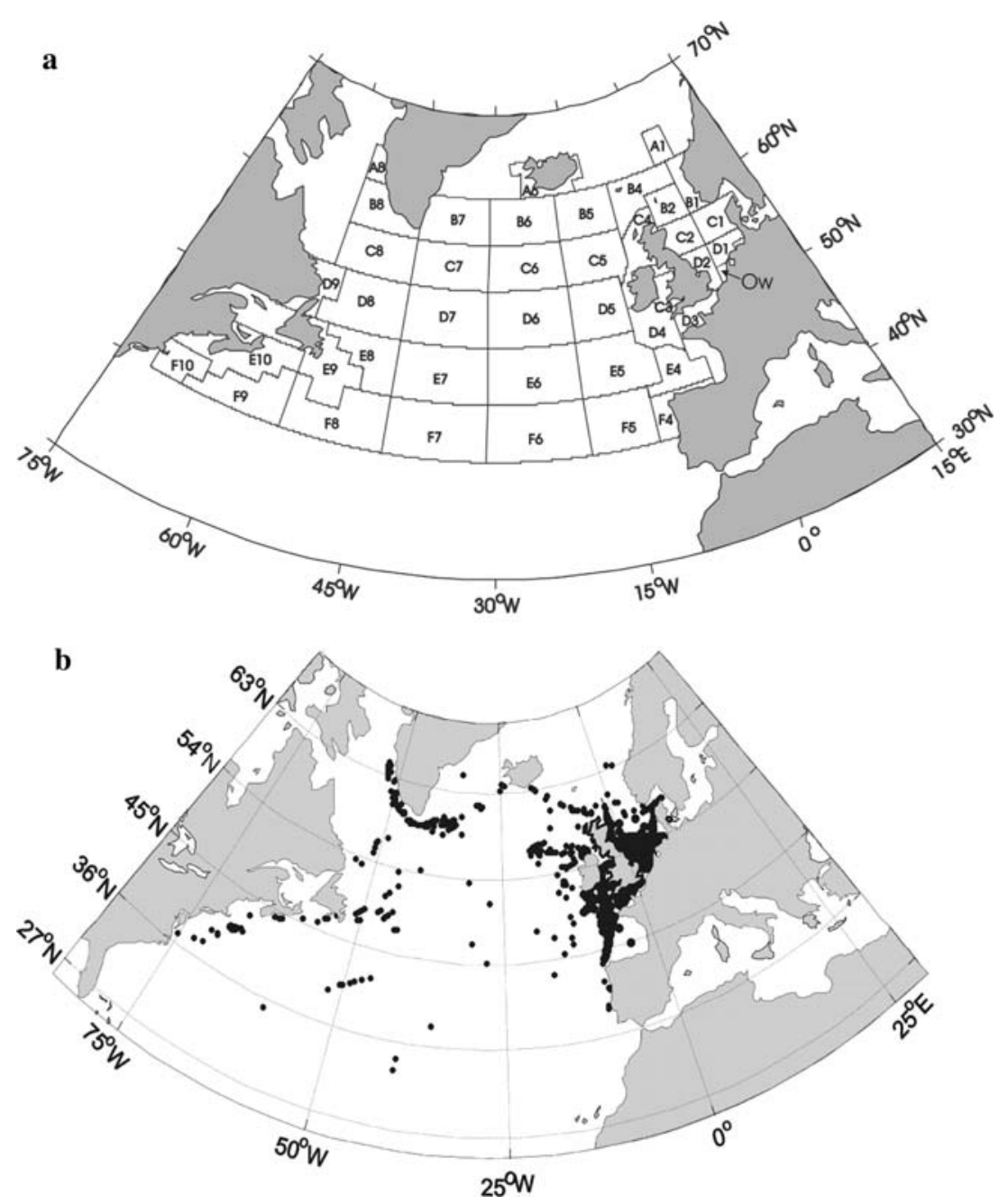
Netherlands since the early 1970s and analysed here (Fig. 4) have been measured by fluorometry and later by high-performance liquid chromatography (HPLC). These data, also those of Rhine river discharge, are available free of charge to the public on the internet because Rijkswaterstaat is a government agency funded by taxes; waterbase is the keyword for access. Briefly, samples are taken near the surface; they are considered to be representative for the whole water column because normally Dutch coastal waters are mixed from the surface to bottom by tides and wind. Information on the frequency of sampling, the station network, numbers of samples taken, and other details of the sampling procedure are implicit in the data set that can be extracted by using waterbase. We have chosen section Noordwijk $(\mathrm{N})$ of this programme because it starts just north of the Rhine outflow and samples taken there are likely to be influenced most by this river. The numbers (N2, N10, etc.) refer to the number of kilometers from the coast.

\section{Data presentation}

The monthly mean phytoplankton and Phaeocystis plots presented here (months versus years, 1948-2003) are so-called Hovmöller diagrams, two-dimensional (2D) plots are often used to display large amounts of data in a readily understandable way (Hovmöller 1949); the computing and statistical analysis has been presented by Leterme et al. (2005). In order to reveal anomalies in the trends in the North Sea more clearly, the Phytoplankton Colour index (PCI) (chlorophyll) and Phaeocystis colony percent frequencyof-occurrence data were also standardized to zero mean and unit variance in the North Sea survey regions D1, D2, C1 and C2 together (refered to herein as 'the North Sea'), the cumulative sums method (Ibañez et al. 1993). The calculation consists of subtracting a reference value (here the mean of the series) from the data. The residuals are then successively added, forming a cumulative function. Cumulative sum plots have been introduced into the SAHFOS data set interpretation (Beaugrand et al. 2000) to summarise major changes and identify transitional periods in phytoplankton time series. The cumulative function results in the smoothing of high-frequency interannual variability and highlights changes in mean values along the time series.

\section{Results}

The distribution of Phaeocystis colonies over the North Sea and the North Atlantic (Fig. 1b) seems to support the notion of an ocean-wide species with peak abundance in spring everywhere (Fig. 2). The centre of abundance over the study period, spanning five decades, was restricted nearly entirely to the North Sea, with the southeastern part clearly being a hotspot. In the open and central Atlantic regions the long record suggests low (cf. Owens et al. 1989) but persistent occurrence (Fig. 2). Abundance was also low (but equally persistent) in the northern North Sea (regions $\mathrm{C} 1$ and $\mathrm{C} 2$ ) where Atlantic water flows in from the northwest and dominates the water budget. Low colony frequencies were seen (only until 1985) in the front between the North Atlantic current in the Irminger Sea and the East Greenland current, south of Greenland (Figs. 1b and 2); the season of highest occurrence was spring also there.

Annual variation of Phaeocystis colony abundance did not at all resemble the variation in phytoplankton biomass [the chlorophyll-related Phytoplankton Colour index (PCI)] anywhere, certainly not in the bloom period, i.e. the spring (see Fig. 3). Year-month plots of true chlorophyll concentrations, derived from the Dutch monitoring programme, in $\mathrm{CPR}$ rectangle 'Ow' (see Fig. 1b) are presented in Fig. 4. Notice the gradually earlier chlorophyll spring bloom over the monitoring period at all stations $(2,10,20$ and $70 \mathrm{~km}$ off the coast of Noordwijk, The Netherlands).

The Phytoplankton Colour (PCI) cumulative sum plot showed a (single) shift (Fig. 5) in the mid 1980s. This was very different from the two shifts in the Phaeocystis plot (mid 1960s and early 1990s, see Fig. 5), which shows again that Phaeocystis does not reflect the variation observed in phytoplankton biomass. Between 1970 and 1985, low phytoplankton abundance (PCI) in the North Sea coincided with a late spring bloom. This 

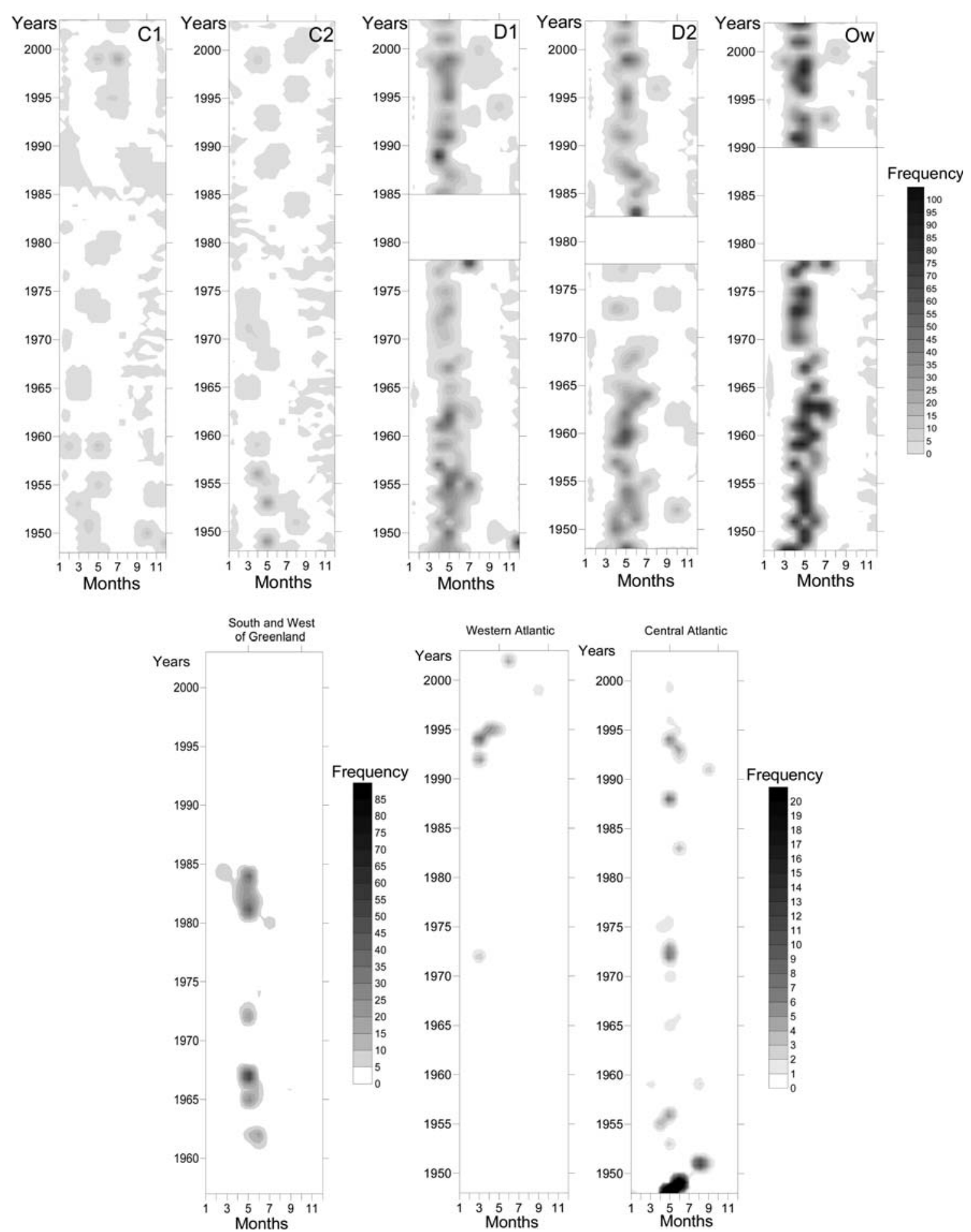

Fig. 2 Hovmöller diagrams (years 1948-2003 versus months) of Phaeocystis frequency in different regions of the North Sea and the Atlantic Ocean (see Fig. 1b for the location of the regions). Rectangle 'Ow' is the southeastern part of the Southern Bight of the North Sea, directly off the

Netherlands. South and West Greenland corresponds to the regions A8, B7 and B8 (see Fig. 1). Western Atlantic regrouped regions E9, E10 and F10. Central Atlantic corresponds to regions E5 to E8 and D5 to D8 

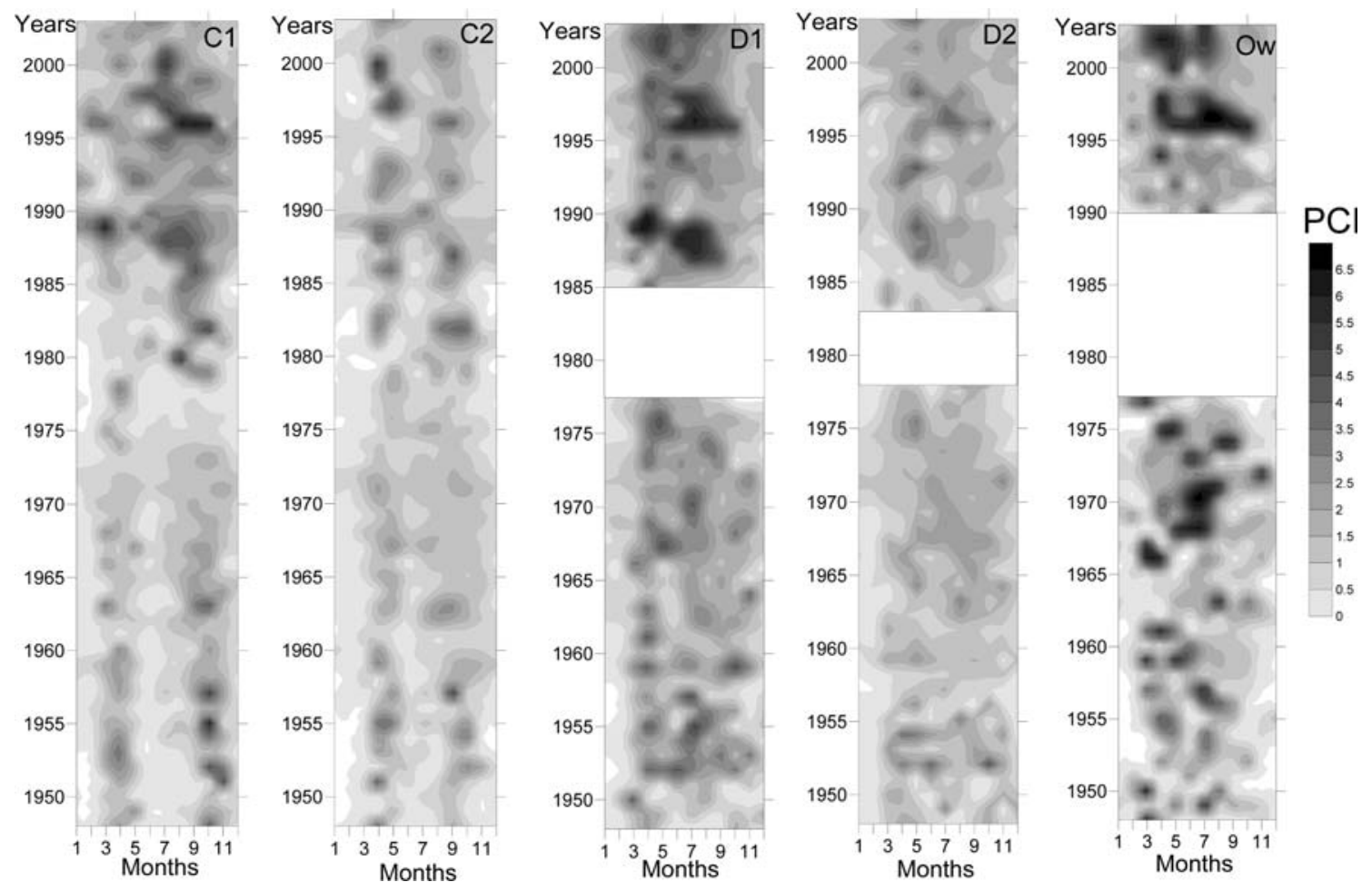

Fig. 3 Hovmöller diagrams (years 1948-2003 versus months) of the Phytoplankton Colour index (PCI) in the North Sea. For region location see Fig. 1b. Rectangle 'Ow'

pattern is in contrast with a high frequency of occurrence of Phaeocystis and its long season of presence before 1955. After 1995 the Phaeocystis season was again longer, an observation confirmed by Breton et al. (2006) who described the Phaeocystis record since 1988 off the Belgian coast, and by the Phaeocystis record of Philippart, Cadeé and van Iperen (not published) that covers the period 1975-2006.

\section{Discussion}

The distribution map of Phaeocystis presented here can hardly be improved, not even by ocean colour remote sensing: the frequent cloud cover over the North Atlantic hinders satellite-borne observations, but not the CPR survey. Also, the pigment signature of Phaeocystis is not very specific (Antajan et al. 2004) so the absorption spectrum and therewith the light reflectance hardly differs from that of other fucoxanthin- and fucoxanthin-derivative-containing phytoplankton is the southeastern part of the Southern Bight of the North Sea, directly off The Netherlands

groups, frustrating remote distinction of this particular species group. Without the survey it would not have been possible to construct the detailed year-month diagrams spanning many decades; those of low but persistent Phaeocystis occurrence in spring far offshore in the mid-Atlantic regions (Fig. 2) and in the Atlantic water of the northern North Sea, in areas C1 and C2 (Fig. 2) are probably the most unexpected. Not only in neritic water but apparently also in the open Atlantic, far away from anthropogenic nutrient sources (eutrophication), environmental conditions are clearly quite suitable for lifecycle development from single cells to colonies (the only stage recorded during the CPR survey).

Even so, changes in eutrophication have often been invoked to explain variation in Phaeocystis abundance and length of the season of blooming and occurrence, but this interpretation has not been satisfactory in view of the restricted number of stations, often limited to just one (Hickel et al. 1996; Cadée and Hegeman 2002). Breton et al. (2006), who also used observations at a single 

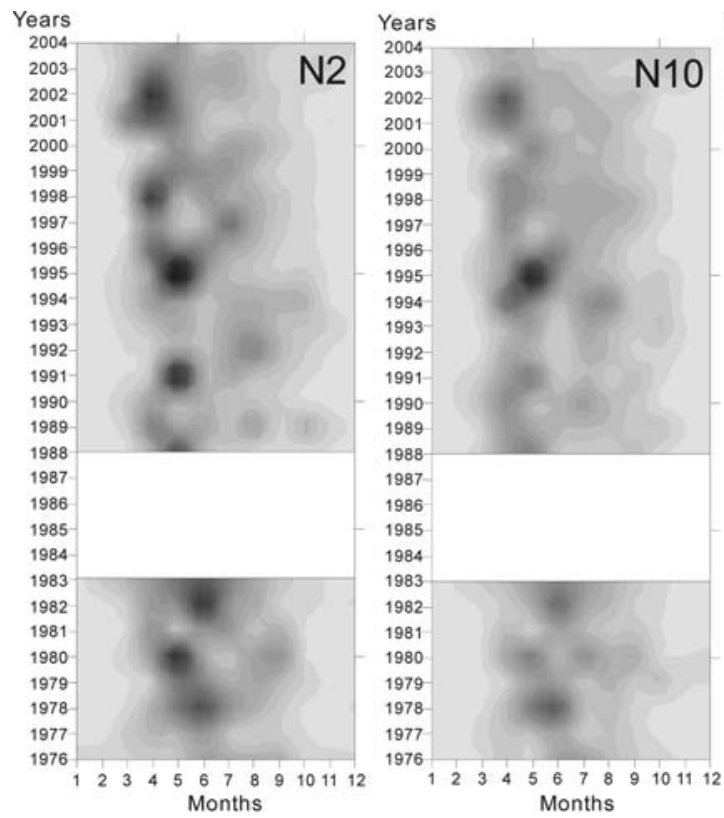

Fig. 4 Hovmöller diagrams of chlorophyll-a concentration on a section perpendicular to the Dutch coast starting from the city of Noordwijk (just north of the river Rhine

station (off Belgium), drew attention to the influence of larger-scale phenomena, namely the North Atlantic Oscillation that governs climate. Much earlier, an analysis of CPR survey results obtained in the same area had revealed trends of Phaeocystis (Gieskes and Kraay 1977a) that did not simply follow the eutrophication trend (Philippart et al. 2000): a decrease of Phaeocystis frequency of occurrence in the 1960s and early 1970s, a period when anthropogenic nutrient input in the southeastern North Sea increased.

The higher frequency of occurrence and longer growing season of Phaeocystis before 1965, when eutrophication was still quite low (Philippart et al. 2000), is particularly striking (Figs. 2, 5). Actually, colony abundance was already reported to be extensive more than 80 years ago (Savage 1930). This also suggests that Phaeocystis abundance is not determined by anthropogenic nutrient input only. On the other hand, phytoplankton biomass in general has always suggested a direct relation with eutrophication (Cadée and Hegeman 2002). Also in our study a relationship can be established between chlorophyll concentrations measured off the Dutch coast (Fig. 4) and river run-off

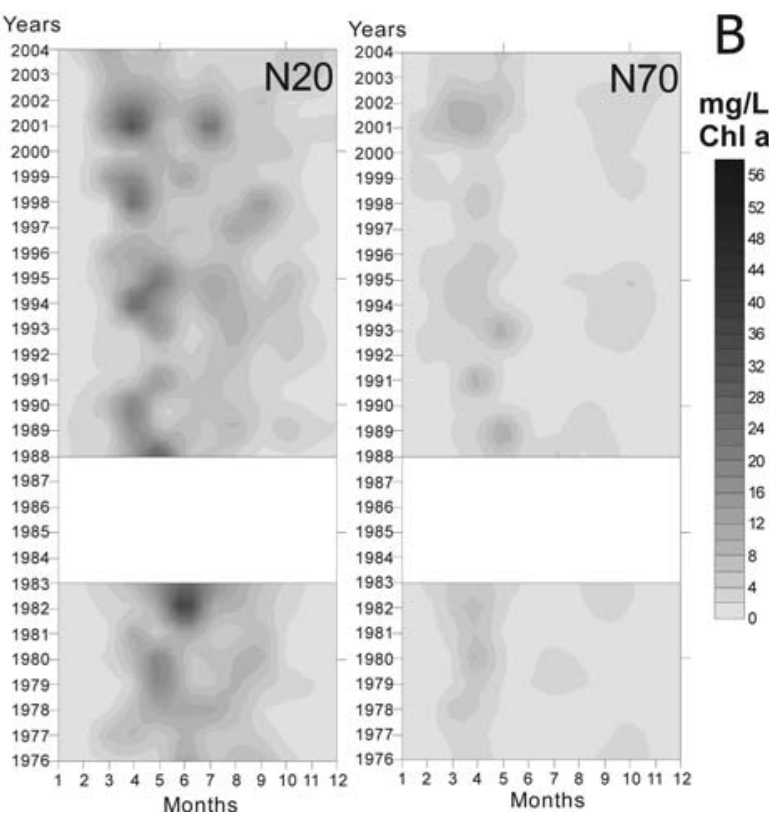

outflow), at 2,10, 20 and $70 \mathrm{~km}$ from the coast. Notice the gradual shift of the start of the vegetative season to an earlier date at all four stations

(not shown), which confirms previous findings by Schaub and Gieskes (1991); recently Breton et al. (2006) have also pointed out this link. Increased nutrient availability of North Sea coastal waters after high freshwater fluxes following periods of heavy rainfall (a response to the North Atlantic Oscillation, cf. Breton et al. 2006) in the catchment area of the continent's rivers clearly sets the stage for phytoplankton abundance in the southeastern North Sea. Such a batch culture-like response to nutrient enrichment (light is apparently not limiting primary production here) can be observed to the present day (Fig. 4). It can readily be explained by nutrient flushed out from the agricultural lands along the continent's rivers, and probably also resuspension of nutrient-rich bottom sediment when river flow is rapid after heavy downpours upstream; Schaub and Gieskes (1991) stated that phytoplankton biomass near the Dutch coast can be predicted on the basis of meteorological data on precipitation, which has now also been suggested for Belgian coastal waters by Breton et al. (2006). There is a suggestion of a gradual shift of the start of the growing season to an earlier date in the southern North 

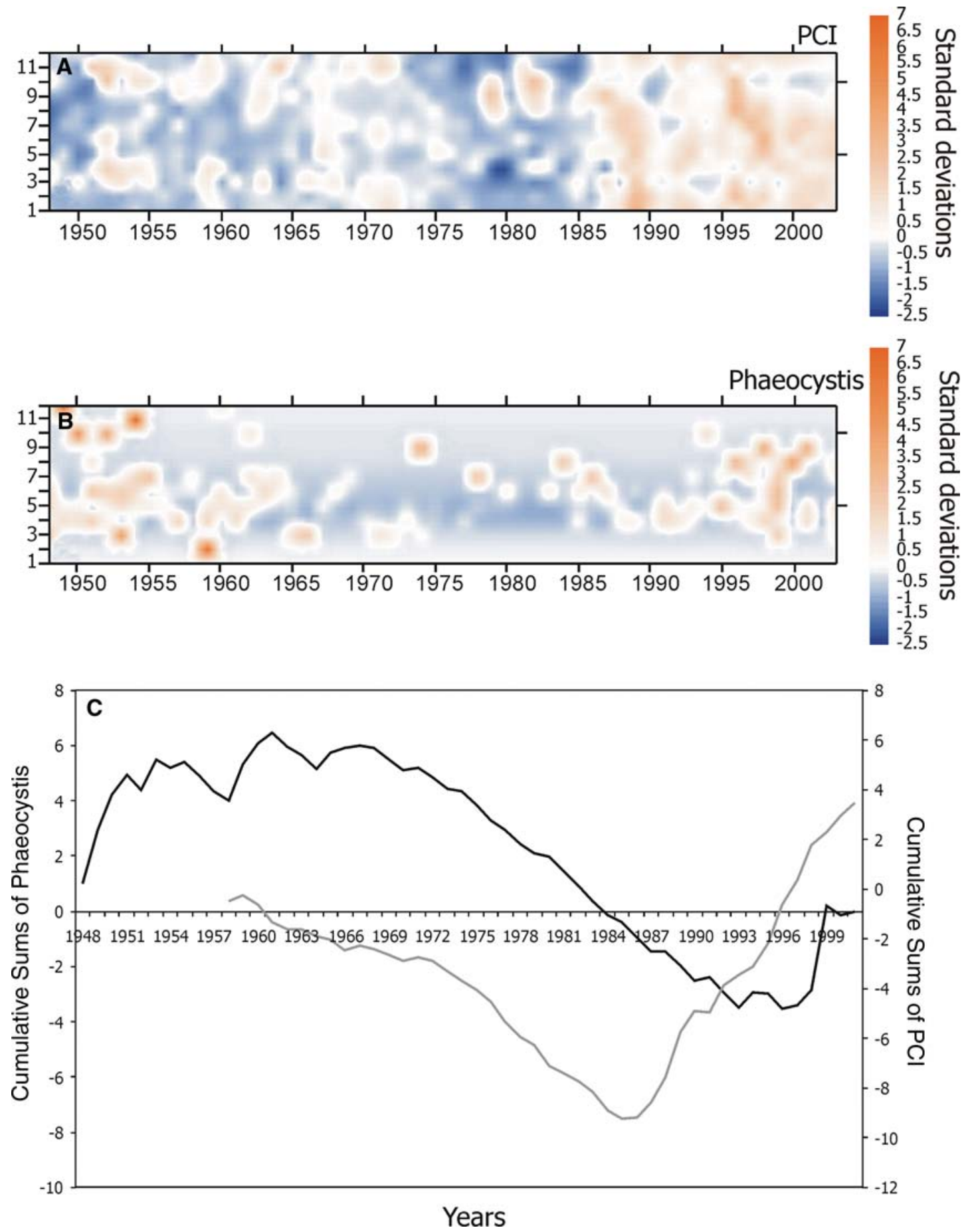

Fig. 5 Hovmöller diagrams, years 1948-2003 versus months of the year of: (A) standard deviations of the phytoplankton colour index (PCI), (B) standard deviations of Phaeocystis occurrence frequency, data averaged over North Sea regions C1, C2, D1 and D2 (cf. Fig. 1a). and (C) cumulative sum (see "Materials and methods" section) plots of mean phytoplankton colour index (PCI, in gray) and Phaeocystis frequency of occurrence (black) for the same region 
Sea (Fig. 4). Whether or not this is the consequence of a slight but gradual warming of southern North Sea waters remains to be shown.

The Phaeocystis component of the phytoplankton is not necessarily related to river-induced eutrophication: long-term changes of Phaeocystis are quite different from those of the phytoplankton (as Phytoplankton Colour index PCI, i.e. chlorophyl, in the "Materials and methods" section) in general (Fig. 5). As we have seen above, environmental conditions in open ocean water, not necessarily those of coastal waters, promote colony development from single cells. Atlantic water inflow into the North Sea may therefore well be an important factor for the development of Phaeocystis in the southern North Sea, a suggestion made earlier for phytoplankton in general by De Jonge et al. (1996) and De Jonge (1997). The inflow of Atlantic water into the North Sea through the Dover Straits has unfortunately never been monitored over longer periods; it has usually been no more than deduced, e.g. from the potential induced in submarine cables by the water flow (Prandle 1978), most often by constructing hydrodynamic models that simulate currents on the basis of tides, wind stress over the North Sea and freshwater input (Salomon et al. 1993; Laane et al. 1996; Skogen and Søiland 1998; Siegismund 2001). Rather sudden changes in climate-ocean interactions that influenced regime shifts in North Sea ecosystem components took place in the late 1970s, late 1980s and late 1990s (Weijerman et al. 2005). The long-term changes in Phaeocystis described here (Fig. 5) do not correspond well with these regime shift periods, probably because both variability in the mix of nutrient sources in the southern North Sea and in the sampling route of the plankton recorders do not allow corresponding biological and hydrographical observations.

Phaeocystis has been reported to accumulate preferentially far offshore, not on the coast, in the southern North Sea in the 1920s (Savage 1930). Later, Gieskes and Kraay (1977b) also described preferential abundance offshore. According to Brunet et al. (1996) accumulation on French beaches of the British Channel is the effect of eastward transport of offshore Phaeocystis blooms, not of in situ growth. The line of increased abundance off the southern coasts of Greenland, in the region of the front between the extension of the North Atlantic current in the Irminger Sea and the East Greenland current (Fig. 1b), may be explained in these terms. In view of the current system the Phaeocystis distribution here suggests advection from the Denmark Straits or even from the west coast of Iceland (regions not covered by the CPR survey), where Phaeocystis has been reported to be abundant (Thordardottir and Astthorsson 1986; Stefansson and Olafsson 1991). The total absence of colonies since 1985 can be explained simply (albeit speculatively) by assuming a shift in the front to an area outside the plankton recorder routes.

Offshore accumulation of Phaeocystis along frontal zones as suggested here may well be a more general phenomenon; in the southern North Sea it would explain an apparent dependence on the inflow of Channel/Atlantic water through the Dover Straits, a source of nutrients in this region that can be more important than local river sources of nutrients (Radach and Lenhart 1995; Laane et al. 1996; De Jonge et al. 1996; De Jonge 1997). The high Phaeocystis abundance far off the Netherlands, all the way between Holland and England in 1925 and 1926 (Savage 1930), can be understood in this light. The Atlantic Ocean water mass entering the North Sea from the southeast forms a front with the coastal water off the coasts of Belgium and the Netherlands. Interestingly, part of the decrease of Phaeocystis abundance in the CPR record in the 1960s and 1970s may be explained by a change of the position of the front, in line with the suggested front shift south of Greenland that may have brought Phaeocystis out of the reach of the CPR survey in that region. In the southeastern North Sea the sampling route of the CPR survey has remained the same geographically while the coastal water/ ocean water front has shifted up to $20 \mathrm{~km}$ eastward to shallow Dutch coastal waters since the gradual man-made closure of the estuaries in the south-estern Netherlands following the catastrophic storm surge of 1953 (J. de Kok and L. Villerius, Rijkswaterstaat-RIKZ, pers. comm.).

Wind forcing may of course broaden the Rhine plume considerably, especially when winds from 
the east persist (Gieskes 1974). Wind forcing, later often suggested to be a dominant factor in setting the stage for water mass distribution and flow in the North Sea (Salomon et al. 1993; Laane et al. 1996; Smith et al. 1996; Pingree 2005), is a parameter with a long-term measurement record at many meteorological stations along the coasts. Exploitation of such data to hindcast and predict large-scale current patterns would enhance and improve existing models to estimate inflow of Atlantic Water through the Dover Straits. These models currently produce contradictory results, and no trend has so far been revealed (Otto et al. 1990). Low phytoplankton abundance in the North Sea and a late spring bloom and changes in other ecosystem components between the mid 1970s and the late 1980s have been ascribed to a cold-water period considered to be the consequence of low Atlantic water inflow into the North Sea (Corten and van de Kamp 1992, 1996; Lindeboom et al. 1995; Taylor et al. 1998; Edwards et al. 2002; Weijerman et al. 2005). It is well known that biological responses may magnify changes in the physical or chemical environment, and the annual variation of Phaeocystis colony occurrence in the southeastern North Sea may well be an example of this concept.

Phaeocystis plays a key role in element fluxes relevant to climate (reviewed by Schoemann et al. 2005) and therefore the results presented here have implications for biogeochemical models of cycling of carbon and sulphur. Sea-to-air exchange of carbon dioxide $\left(\mathrm{CO}_{2}\right)$ and dimethyl sulphide (DMS) has been calculated on the basis of measurements made during cruises in a single year. Manizzi et al. (2005) already issued a warning to prevent this practice. Thomas et al. (2004) presented $\mathrm{CO}_{2}$ fluxes in the southern North Sea based on measurements from August 2001 to May 2002 only. They concluded that coastal seas would take up $0.4 \mathrm{Pg} \mathrm{C}$ per year. In view of the large annual variation both in phytoplankton and in Phaeocystis abundance presented in this paper such extrapolations cannot be correct. Discrepancies noted by Thomas et al. (2004) with results obtained in the same area by Borges and Frankignoulle (2003) may well have been the consequence of differences in plankton activity between the years in which the cruises were carried out.
Acknowledgements Financial support from the Dutch Royal Academy of Sciences (KNAW) allowed W.W.C.G. to spend a sabbatical at the Sir Alister Hardy Foundation of Ocean Sciences in Plymouth (UK); the SAHFOS directory is gratefully acknowledged for generous hospitality. We thank the Dutch National Institute for Coastal and Marine Management (RIKZ) for access to their monitoring data through waterbase, and a group of students of Groningen University coached by Rob Middag for the analyses. Comments by two unknown referees and editing by $\mathrm{Dr}$ M.A. van Leeuwe have improved the manuscript considerably. We acknowledge the assistance of the reviewers, and of colleagues who inspected earlier versions of the manuscript.

\section{References}

Antajan E, Chrétiennot-Dinet M-J, Leblanc C, Daro M-H, Lancelot C (2004) 19'Hexanoyloxyfucoxanthin may not be the appropriate pigment to trace occurrence and fate of Phaeocystis: the case of P. globosa in Belgian coastal waters. J Sea Res 52:165-177

Batten SD, Walne AW, Edwards M, Groom SB (2003) Phytoplankton biomass from continuous plankton recorder data: an assessment of the phytoplankton colour index. Plankton Res 25:697-702

Beaugrand G (2004) The North Sea regime shift: evidence, causes, mechanisms and consequences. Progr Oceanogr 60:245-262

Beaugrand G, Ibañez F, Lindley JA (2003) An overview of statistical methods applied to CPR data. Progr Oceanogr 58:253-262

Beaugrand G, Ibañez F, Reid PC (2000) Spatial, seasonal and long-term fluctuations of plankton in relation to hydrodynamic features in the English Channel, Celtic Sea and Bay of Biscay. Mar Ecol Progr Ser 200:93-102

Beaugrand G, Reid PC, Ibañez F, Lindley JA, Edwards M (2002) Reorganization of North Atlantic marine copepod biodiversity and climate. Science 296:16921694

Borges AV, Frankignoulle M (2003) Distribution of surface carbon dioxide and air-sea exchange in the English Channel and adjacent areas. J Geophys Res 108(C5):3140 (doi:10. 1029/2000JC 000571)

Breton E, Rousseau V, Parent J-Y, Ozer J, Lancelot C (2006) Hydroclimatic modulation of diatom/Phaeocystis blooms in nutrient-enriched Belgian coastal waters (North Sea). Limnol Oceanogr 51:1401-1409

Brunet C, Brylinski JM, Bodineau L, Thommelin G, Bentley D, Helde D (1996) Phytoplankton dynamics during the spring bloom in the south-eastern Channel. Estuar Coast Shelf Sci 43:469-483

Cadée GC, Hegeman J (1991) Historical phytoplankton data of the Marsdiep. Hydrobiol Bull 24:111-118

Cadée GC, Hegeman J (2002) Phytoplankton in the Marsdiep at the end of the 20th century; 30 years monitoring biomass, primary production, and Phaeocystis blooms. J Sea Res 48:97-110 
Colebrook JM (1975) The continuous plankton recorder survey: automatic data processing methods. Bull Mar Ecol 8:123-142

Colebrook JM, Robinson GA (1964) Continuous plankton records: annual variability of plankton, 1948-1960. Bull Mar Ecol 6:52-69

Corten A, van de Kamp G (1992) Natural changes in pelagic fish stocks of the North Sea in the 1980s. ICESMar Sci Symp 195:402-417

Corten A, van de Kamp G (1996) Variation in the abundance of southern fish species in the southern North Sea in relation to hydrography and wind. ICES J Mar Sci 53:1113-1119

De Jonge VN (1997) High remaining productivity in the Dutch Western Wadden Sea despite decreasing nutrient inputs from riverine sources. Mar Poll Bull 34:427436

De Jonge VN, Bakker JF, van Stralen M (1996) Recent changes in the contributions of river Rhine and North Sea to the eutrophication of the western Dutch Wadden Sea. Neth J Aq Ecol 30:27-39

Drinkwater KF, Belgrano A, Borja A, Conversi A, Edwards $\mathrm{M}$, Greene $\mathrm{CH}$, Ottersoen $\mathrm{G}$, Pershing AJ, Walker H (2003) The response of marine ecosystems to climate variability associated with the North Atlantic Oscillation: climatic significance and environmental impact. Geophys Monogr 134:211-234 (Amer. Geophys. Union)

Edwards M, Beaugrand G, Reid PC, Rowden AA, Jones MB (2002) Ocean climate anomalies in the ecology of the North Sea. Mar Ecol Progr Ser 239:1-10

Fromentin JM, Planque B (1996) Calanus and environment in the eastern North Atlantic. II. Influence of the North Atlantic Oscillation on C. finmarchicus and $C$. helgolandicus. Mar Ecol Progr Ser 134:111-118

Gieskes WWC (1974) Phytoplankton and primary productivity studies in the Southern Bight of the North Sea, eastern part, in 1972. Ann Biol 29:54-61

Gieskes WWC, Kraay GW (1977a) Continuous plankton records: changes in the plankton of the North Sea and its eutrophic Southern Bight from 1948 to 1975 . Neth J Sea Res 11:334-364

Gieskes WWC, Kraay GW (1977b) Primary production and consumption of organic matter in the southern North Sea during the spring bloom of 1975 . Neth J Sea Res 11:146-167

Glover RS (1967) The continuous plankton recorder survey of the North Atlantic. Symp Zool Soc Lond 19:189-210

Greve W, Reimers F, Nast J (1996) Biocoenotic changes of the zooplankton in the German Bight: the possible effects of eutrophication and climate. ICES J Mar Sci 53:951-956

Hickel W, Eickenhoff M. Spindler H, Berg J, Raabe T, Mueller R (1996) Auswertungen von Langzeituntersuchungen von Naehrstoffen und Phytoplankton in der Deutschen Bucht. Berlin (UBA) 213 pp

Hovmöller E (1949) The trough and ridge diagram. Tellus 1:62-66

Ibañez F, Fromentin JM, Castel J (1993) Application de la méthode des sommes cumulées à l'analyse des séries chronologiques océanographiques. CR Acad Sci Paris, Sciences de la vie/Life sciences 316:745-748

Kane J (2005) The demography of Calanus finmarchicus (copepoda, calanoida) in the middle Atlantic Bight, USA, 1977-2001. J Plankton Res 27:401-414

Laane RWPM, Groeneveld G, de Vries A, van Bennekom AJ, Sydow JS (1996) Nutrients (P, N, Si) in the Channel and the Dover Strait: seasonal and year-to-year variation and fluxes to the North Sea. Oceanol Acta 16:607-616

Leterme SC, Edwards M, Seuront L, Attrill MJ, Reid PC, John AWG (2005) Decadal basin-scale changes in diatoms, dinoflagellates, and phytoplankton color across the North Atlantic. Limnol Oceanogr 50:1244-1253

Lindeboom H, Raaphorst W, Beukema J, Cadée GC, Swennen C (1995) (Sudden) changes in the North Sea and Wadden Sea: oceanic influences underestimated? Dt Hydrogr Z Suppl 2:87-100

Lindley JA, Roskell J, Warner AJ, Halliday N, Hunt HG, John AWG, Jonas TD (1990) Doliolids in the German Bight in 1989:evidence for exceptional inflow into the North Sea. J Mar Biol Ass UK 70:679-682

Manizzi M, Metzl N, Le Quéré C (2005) Interannual variability of the ocean carbon cycle. SOLAS News 1:1011

Martin JHA, Hall WB (1975) Changes in physical, chemical and phytoplankton parameters in the northern North Sea, 1961-1970. ICES, CM 1975/C:33:1-4

Otto L, Zimmermann JTF, Furnes GK, Mork M, Saetre R, Becker G (1990) Review of physical oceanography of the North Sea. Neth J Sea Res 26:161-238

Owens NJP, Cook D, Colebrook M, Hunt H, Reid PC (1989) Long-term trends in the occurrence of Phaeocystis sp. In the North-East Atlantic Ocean. J Mar Biol Ass UK 69:813-821

Philippart CJM, Cadée GC, van Raaphorst W, Riegman R (2000) Long-term phytoplankton-nutrient interactions in a shallow coastal sea: algal community structure, nutrient budgets, and denitrification potential. Limnol Oceanogr 45:131-144

Pingree RD (2005) North Atlantic and North Sea Climate Change: curl up, shut down, NAO and Ocean Colour. J Mar Biol Assoc UK 85:1301-1315

Prandle D (1978) Monthly mean residual flow through the Dover Strait, 1949-1972. J Mar Biol Ass UK 58:965973

Radach G (1984) Variations in the plankton in relation to the climate. Rapp P-v Reun Cons Int Explor Mer 185:234-254

Radach G, Lenhart HJ (1995) Nutrient dynamics in the North Sea: fluxes and budgets in the water column derived from ERSEM. Neth J Sea Res 33:301-335

Reid PC, Borges MF, Svendsen E (2001) A regime shift in the North Sea circa 1990. Fish Res 50:163-171

Reid PC, Edwards M (2001) Long-term changes in the pelagos, benthos and fisheries of the North Sea. Senckenb Marit 31:107-115

Reid PC, Edwards M, Beaugrand G, Skogen M, Stevens D (2003) Periodic changes in the zooplankton of the North Sea during the 20th century linked to oceanic inflow. Fish Oceanogr 12:260-269 
Reid PC, Planque B, Edwards M (1998) Is observed variability in the long-term results of the continuous plankton recorder survey a response to climate change? Fish Oceanogr 7:282-288

Richardson K (1989) Algal blooms in the North Sea: the good, the bad and the ugly. Dana 8:83-89

Richardson K (1997) Harmful or exceptional blooms in the marine ecosystem. Adv Mar Biol 31:301-385

Russell FS (1935) On the value of certain plankton animals as indicators of water movements in the English Channel and North Sea. J Mar Biol Ass UK 20:309-331

Russell FS (1973) A summary of the observations on the occurrence of plankton stages of fish off Plymouth, 1924-1972. J Mar Biol Ass UK 53:347-355

Russell FS, Southward AJ, Boalch GT, Butler EI (1971) Changes in biological conditions in the English Channel off Plymouth during the last half-century. Nature (Lond) 234:468-470

Salomon JC, Breton M, Guéguénat P (1993) Computed residual flow through the Dover Strait. Oceanol Acta 16:449-455

Savage RE (1930) The influence of Phaeocystis on the migration of the herring. Fishery Invest II, XII(2):5-13

Schaub BEM, Gieskes WWC (1991) Eutrophication of the North Sea: the relation between Rhine river discharge and chlorophyll-a concentration in Dutch coastal waters. In: Estuaries and coasts: spatial and temporal intercomparisons. ECSA 19 Symposium. Publ. Olsen and Olsen, pp 85-90

Schoemann V, Becquevort S, Stefels J, Rousseau V, Lancelot C (2005) Phaeocystis blooms in the global ocean and their controlling mechanisms: a review. J Sea Res 53:43-66
Seuront L, Souissi S (2001) Climatic control of Phaeocystis spring bloom in the eastern English Channel (19912000). La Mer 40:41-51

Siegismund F (2001) Long-term changes in the flushing times of the ICES-boxes. Senckenb Marit 31:151-167

Skogen M, Søiland H (1998) A user's guide to NORWECOM v2.0. The Norwegian Ecological Model system. Tech. Rep. Fisken og Havet 18/98. Institute of marine Research, Pb.1870, N-5024 Bergen. 42 pp

Smith JA, Damm P, Skogen MD, Flather RA, Paetsch J (1996) An investigation into the variability of circulation and transport on the North-west European shelf using three hydrodynamic models. German J Hydr $8: 325-348$

Stefansson U, Olafsson J (1991) Nutrient and fertility of Icelandic waters. Rit Fiskideildar 12:1-56

Taylor AH, Jordan MB, Stephens JA (1998) Northward shifts of the Gulf Stream following ENSO events. Nature 393:638

Thomas H, Bozec Y, Elkelay K, de Baar HJW (2004) Enhanced open ocean storage of $\mathrm{CO}_{2}$ from shelf sea pumping. Science 304:1005-1008

Thordardottir T, Astthorsson OS (1986) Chlorophyll a and zooplankton distribution in Icelandic waters in spring 1982, 1983 and 1984. Ann Biol 41:63-66

Warner A, Hays GC (1995) Sampling by the continuous plankton recorder survey. Prog Oceanogr 34:237-256

Weijerman M, Lindeboom H, Zuur AF (2005) Regime shifts in marine ecosystems of the North Sea and the Wadden Sea. Mar Ecol Prog Ser 298:21-39 